\title{
A Part of History That Has Never Been Lost
}

\author{
Farras Kartika Kusumadewi, Moses Glorino Rumambo Pandin \\ Faculty of Humanities, Universitas Airlangga \\ Email: farras.kartika.kusumadewi-2020@fib.unair.ac.id, \\ moses.glorino@fib.unair.ac.id
}

\begin{abstract}
There have been many cases of racism in its history that have occurred from ancient times to the present. Many factors cause racial conflicts. Factors that often trigger these actions, among others, are due to injustice, oppression, and racial discrimination by certain groups against other groups. In America itself, the era of slavery was a dark period in American history. This article aims to find out the impact and solutions to the problem of racism in general. How to find out the impact and solution to the problem of racism is to examine some of the cases that have occurred recently. The method used in this research is qualitative-descriptive with a literature review method to analyze data with 20 sources from books, journal articles, theses and websites. The findings of this study reveal that cases of racism still occur today, for example, last year because of the COVID-19 problem that initially occurred in Wuhan, China, Asian people received hatred from citizens and Western media. There are many factors that cause racial conflict, and the triggers vary in each country that experiences it, among others, because of injustice, oppression, and racial discrimination by certain groups against other groups. Through cases of racism that have occurred, one thing that according to the researcher can be concluded is how before the conflict between groups occurred, actually it started from problems that occurred between individuals. Tolerance is the main thing to stem this kind of thing.
\end{abstract}

Keywords: racial conflict, society, racism

\section{Introduction}

Racial issues in modern society are still a hot topic today, even though modern society upholds independence and human values are the most essential human rights. ${ }^{1}$ Seen in history, the problem of racism has existed for a long time in various parts of the world. Based on several sources obtained using literature studies, Komnas HAM recorded at least 101 cases of racial and ethnic discrimination in the 2011-2018 period that were reported to them. The diversity that exists in Indonesia is a nation's wealth, but on the

\footnotetext{
${ }^{1}$ Wahono et al., Reformasi Hukum Terhadap Kebijakan Diskriminasi Ras Dan Etnis Di Indonesia (Jakarta: Solidaritas Nusa Bangsa (Organization); Asia Foundation, 2003).
} 
A Part of History That Has Never Been Lost | Farras Kartika Kusumadewi, Moses Glorino Rumambo Pandin

other hand it is very prone to trigger conflicts and divisions. This ethnic plurality is one of the characteristics of Indonesian society that should be proud of. However, there is a very crucial thing that most of us do not realize that this plurality has saved a lot of potential for a conflict to occur that can threaten the life of the nation and state. It is proven that in several areas in our beloved country Indonesia, conflicts occur, such as in Sampit (between the Madurese and Dayak tribes), in Poso (between Christian and Muslim tribes), in Aceh (between $G A M$ and $R I$ ), or student fights between school. This also causes racial differences.

In America, the era of slavery was a dark period in American history. Slavery began in 1619, which was practiced by Native Americans as whites against black Africans. This incident gave rise to perceptions and prejudices about racism that have been ingrained in American society, especially among the white elite. ${ }^{2}$ In addition to racism against black people, there is also racism against Asian races. ${ }^{3}$ At the end of 2019 , people were shocked by the outbreak of a virus that emerged in China, namely the corona virus which was officially named by WHO namely COVID-19. The initial location of the occurrence of this virus, namely in Wuhan, China. In early 2020, COVID-19 began to spread to various countries in Asia and Europe. The news about COVID-19 has been widely discussed in the mass media, especially online media regarding the very fast spread of the virus and the large number of deaths due to this virus. Not only focusing on the news of COVID-19, but also on the country of origin of this virus, China. Some Western media portray this virus by cornering and stigmatizing the Chinese population. As in Der Spiegel magazine in Germany, which depicted an Asian man wearing a mask and headlined "Coronavirus. Made in China. When globalization turns into a deadly threat." 4 This will certainly have an impact on

\footnotetext{
2 Andrea Kimberly, "Media Sosial Dalam Pergerakan: Twitter Dan Facebook Sebagai Kampanye Gerakan Black Lives Matter Di Amerika Serikat" (Universitas Katolik Parahyangan, 2018).

${ }^{3}$ Divya Anand and Laura M. Hsu, "COVID-19 and Black Lives Matter: Examining AntiAsian Racism and Anti-Blackness in US Education," Open Journals in Education (OJED) 5, no. 1 (2020): 190-99.

4 "Beijing Murka, Media Jerman Tulis 'Coronavirus Made in China," Warta Ekonomi.co.id, 2020.
} 
A Part of History That Has Never Been Lost | Farras Kartika Kusumadewi, Moses Glorino Rumambo Pandin

discrimination against Chinese residents who live in various parts of the world. $^{5}$

Many factors cause racial conflict, and the triggers vary in each country that experiences it. Factors that often trigger these actions include injustice, oppression, and racial discrimination by certain groups against other groups. Racism appears among high-ranking people forming a global hierarchy of superiority. In all its forms, racism is a human right that is under-recognized as an important problem to find a solution for, especially in America. These problems threaten the lives and rights of millions of people around the world. This article aims to show incidents of racism that occurred in several periods. In addition, it also aims to analyze what are the impacts of racism and how simple solutions are to deal with acts of racism.

\section{Research Method}

This research was conducted qualitatively descriptively with the aim of obtaining in-depth and complete information from the data collected. In this study, the researcher uses a literature review method from various journals, web articles and several books, where these sources can be trusted and accounted for. Using a literature review where this method tends towards analyzing, assessing, and critiquing the topics that will be discussed in previous research. Therefore, research can be realized as an effort to solve problems by comparing the similarities and differences in the data found, classifying the data, assessing the data, and establishing the relationship between one data and other data found. Researchers collect data as accurately and completely as possible from a problem raised in this journal article to find out the real causes, there are aspects that may need to be improved. The collected data are arranged and studied in order and connected to each other as a whole to produce a general picture. Each fact is studied its role and function so that it can be concluded that the depth of a literature study can be measured from the data collected. ${ }^{6}$

The writing of this article was carried out using the literature review method. The literature review method is a method of collecting data through

\footnotetext{
${ }^{5}$ Crusita Maharani S., "Konstruksi Pemberitaan Stigma Anti-China Pada Kasus Covid-19 Di Kompas.Com” (Universitas Islam Negeri Syarif Hidayatullah, 2020).

${ }^{6}$ Mustofa Djaelani, Metode Penelitian Bagi Pendidik, ed. Mei Aulia (Jakarta: PT. Multi Kreasi Satu Delapan, 2010).
} 
A Part of History That Has Never Been Lost | Farras Kartika Kusumadewi, Moses Glorino Rumambo Pandin

a study of library sources. The literature review method is carried out by utilizing existing sources and library materials, both from books or articles, as well as reports on research results from previous studies related to the issues raised in the writing of this article. After getting several references related to the research theme, the material is read for the important points related to the theme, then cites information, analyzes and then summarizes. The summary is complete, then the writing is generalized with relevant theoretical studies so as to form a complete research paper. The references used by researchers come from books, journal articles, theses, and websites. There are 2 books used, 1 book published in 2003 and 1 book published in 2010. The journal articles used are 13 journal articles, with 1 journal in 2007, 1 journal in 2018, 3 journals in 2019, 6 journals in 2020, and 2 journals in 2021. Theses that serve as sources of reference for researchers, totaling 2 theses, 1 thesis in 2018 and 1 thesis in 2020. For reference websites, there are 3 websites with a time span of 2019-2020, one website in 2019 and 2 website in 2020.

\section{Result and Discussion}

The results of this study were obtained through the literature review method from 20 journal articles or theses, books and websites on the internet. Journal articles used as references include published in 2003 as many as 1 reference $(5 \%)$, in 2007 as many as 1 reference $(5 \%)$, in 2010 as many as 1 reference $(5 \%)$, in 2018 as many as 2 references (10\%), year 2019 with 4 references (20\%), 2020 as many as 9 references (45\%), and in 2021 as many as 2 references $(10 \%)$. The sources and data totaling 20 are the results of studies conducted by previous researchers. These reference sources are deemed suitable and relevant to the discussion discussed in this article. The source obtained is used as a reference by the reseacher to support the research of this article to make it more factual and accurate.

\section{Definition of Race, Racism and Its History}

Etymologically, the word race comes from the French 'race', which is from the Latin 'radix' which means "root". In terminology, there are two general meanings that convey the meaning of the term race, namely: first, demographic or human differences based on appearance, such as hair, eyes, skin color, and body shape; descent; hereditary patterns and unique genetic 
A Part of History That Has Never Been Lost | Farras Kartika Kusumadewi, Moses Glorino Rumambo Pandin

models so that they are distinguished from the natives. And the second, namely stating about identity based on character ownership; the quality of a certain character of a population group; the quality of a certain character of a population group; states signs of activity of a population group based on habits, ideas and ways of thinking; a group of people who have the same ancestry, family; and biological meaning which indicates the existence of a subspecies or variety, birth, or occurrence of a particular species. The concept of race in the development of anthropology has changed terms. Anthropologists and other evolutionary scientists have turned from the term race to the term population to discuss genetic differences. Cultural historians and social scientists have re-understood the term race as a cultural category or social construction. This matter is related to Omi and Winant's theory of race formation saying that race is a concept that defines and symbolizes conflict and social interests through disruption to different types of human body. ${ }^{7}$

Racism in the Indonesian Dictionary (2016) is an understanding of how to differentiate humans based on skin color and physical characteristics. Racism is a belief of people's reality, entity, and their features are determined and seen from the anatomical factor of the body or race of a group, not from an assessment of the quality of reason among humans. This view results in people being valued, valued, or viewed based on racial membership. The spread of racism can cause damage to a person's entity and self-confidence to feel that he is in an inferior position. "Inferior" is a feeling that feels he has a physical deficiency which is caused by people who have a viewpoint. and feel that the race is higher, which is called "superior". This racial treatment also varies, ranging from insulting a certain race, physically insulting, making jokes about the person's ethnicity, negative stereotypes, prejudice or even more seriousness of the disorder directly related to physical, such as bullying. Discussing its history, it turns out that racism has existed and has occurred since ancient times, namely around the 1600s to the mid-1800s. At that time in the United States of America, many black people were used by

\footnotetext{
7 Abd Muid N, Mulawarman Hannase, and Iwan Satiri, "Solusi Konflik Rasial Pada Masyarakat Multikultural Dalam Perspektif Al-Qur' an,” Mumtäz 2, no. 2 (2018): 145-76.

8 Jaza Tirahmawan, Bryan Atfis Luthfi Melody, and Muhammad Naufal Nur Ahly, "Rasisme Terhadap Kulit Hitam Dalam Iklan H\&M," Jurnal Audiens 2, no. 1 (2021): 1925 .
} 
A Part of History That Has Never Been Lost | Farras Kartika Kusumadewi, Moses Glorino Rumambo Pandin

the white kuit race as slaves. ${ }^{9}$ The slaves were brought by the British, who were African, brought to Virginia in 1619.

Another racism occurred around 1930 by Nazi Jews at that time. Then this racist began to lead to skintone (skin color). This racism also began to lead to a non-European conception, which was conceptualized by the East, Asia and the like differently. According to these people had backwardnesses such as economy, degree, or thought; regards the biologically determined beginnings of all human history as distinct. Based on the theory put forward by the Nazi race, Northern Europeans, Germans, and other nations were the superior race.

Furthermore, when discussing the history of racism in Indonesia in the past, it occurred during the Dutch colonial era. At that time differences were thought to be rooted in racial differences, "native" was good, then everything "non-native" was evil. Quite a dense conflict occurred between fellow Europeans and disputes between black / dark people who were fellow colonized in the era of colonial life. Meanwhile, Dutch colonialism was formed and thanks to the cooperation between groups, various racial, ethnic backgrounds and skin colors eventually formed colonialism. Likewise, when we joined forces to struggle to overthrow colonialism. The natives are creatures that were created because of this colonial racism. After this ruled population became independent, the colonial racism was not discarded. Instead, it remained, but with a slight change, namely the exchange of positions of the despised and glorified races. In historical records, it is told that the descendants of Europe exploited, tortured, and always made a fortune on the land they controlled. Meanwhile, those who are not white always suffer or are oppressed. Various colonial crimes did occur, but European colonialism at that time also created different kinds of infrastructure such as building highways, cities, schools, libraries, factories, hospitals, amusement buildings, parks, prisons, courts, and soldiers. ${ }^{10}$

\section{Cases of Racism in the World}

There have been many cases of racism that have occurred worldwide, from any country there must be. In Indonesia itself, there were racism cases

\footnotetext{
${ }^{9}$ Farid Hamid Umarela, Nindyta Aisyah Dwityas, and Devi Rosfina Zahra, "Representasi Ideologi Supremasi Kulit Putih Dalam Iklan Televisi," ProTVF 4, no. 1 (2020): 64-84.

${ }^{10}$ Yenita Irab, “Rasisme,” Jurnal Jaffray 5, no. 1 (2007): 50-58.
} 
A Part of History That Has Never Been Lost | Farras Kartika Kusumadewi, Moses Glorino Rumambo Pandin

from the past until now, one of which happened in 2019. Issues and problems of racism against Papuans and the riots that occurred in Papua recorded a new history on the national political stage. This has brought and reminded us of the history of a similar problem, namely the issue of separatism or so-called the issue of self-determination. ${ }^{11}$ Cases that occurred in Surabaya and Malang, reported by The Conversation, Sunday (8/9), August 17, 2019, the incident occurred when the police arrested 43 Papuan students in their dormitory in Surabaya, East Java for allegedly desecrating the Indonesian red and white flag during the Independence Day Award. The police pounded on the gates of the Papuan dormitory in Surabaya, the reason being that they saw a red and white flag posted by the Surabaya city government falling into a ditch. Gradually the police and mass organizations came and surrounded the dormitory for 24 hours. Police shouted various racist insults, and used tear gas to get them out. However, the next day, the 43 Papuan students who were arrested were released by the police because they did not have solid evidence that the residents insulted the national symbol. This incident caused waves of people in Papua to express their disappointment in Jayapura, the capital city of Papua, Manokwari, the capital city of West Papua, and the city of Sorong. In Jayapura, a sea of people marched 18 kilometers from Waena, the city's bustling center, to the governor's office, demanding racism against Papua must be stopped. The Governor of Papua, Lukas Enembe at that time firmly said that "we are not a nation of monkeys, we are humans." ${ }^{12}$

Another case of racism that always sticks in my mind is the case of ethnic Chinese racism. Racial hatred and oppression of ethnic Chinese minorities is still concerning when considering the tragedy of the 1998 riots. One of the causes of this incident is the envy that arises because of the differences in the economic conditions of the indigenous people of ethnic Chinese descent. Things that all started as individuals can explode into a common problem, from which riots can emerge. The case also resulted in discrimination and violent conflict that smelled of ethnic Chinese in Surakarta, Central Java. The ethnic Chinese who live in Surakarta have lived

\footnotetext{
${ }^{11}$ Max Lane, "The Papuan Question in Indonesia: Recent Developments," ISEAS - Yusof Ishak Institute 9, no. 74 (2019): 1-10.

${ }^{12}$ Defira Martina Adrian, Fence M Wantu, and Abdul Hamid Tome, "Diskriminasi Rasial Dan Etnis Dalam Perspektif Hukum Internasional,” Jurnal Legalitas 14, no. 6 (2021): 1-17.
} 
A Part of History That Has Never Been Lost | Farras Kartika Kusumadewi, Moses Glorino Rumambo Pandin

for hundreds of years and live side by side with residents, namely the Javanese. Various sentiments and ethnic conflicts emerged. However, reconciliation and integration efforts are continuously carried out to maintain the peaceful relationship formed between the ethnic Chinese and the Javanese people in Surakarta. ${ }^{13}$ The existence of the Chinese ethnicity in Surakarta contributes to enriching society's diversity, which is proof that there is multiculturalism there. Through the cases of intolerance above, one thing that according to the researcher can be concluded is how before the conflict between groups occurred, it started from problems that occurred between individuals. Tolerance is the main thing to stem this kind of thing. Some of the descriptions above are enough to make us realize that Indonesia, which has a pluralistic population, still lacks tolerance. ${ }^{14}$

It is not only in Indonesia, cases of racism that shocked the world occurred in the United States. As quoted on kompas.com, ${ }^{15}$ the death of a black man named George Floyd, in Minneapolis, led to massive demonstrations in hundreds of cities in the United States. Americans are outraged after the viral video, which shows the moment Floyd's neck was pinned down by Chauvin (a police officer) for nearly nine minutes. In the video Floyd still had time to say "I can't breathe". However, those were the last words Floyd said to Chauvin, before he finally didn't move. Currently, he is charged with three articles, namely third-degree murder, second-degree murder and second-degree manslaughter. The city of Minneapolis where the George Floyd incident was killed is one of the silent witnesses to the history of racism in the US. The city of Minneapolis is inhabited by residents with quite diverse races and cultures. This city is often referred to as a city that deserves to be proud of its success in sowing multiculturalism. But in fact,

\footnotetext{
13 Verbena Ayuningsih Purbasari and Suharno, "Interaksi Sosial Etnis Cina-Jawa Kota Surakarta," Jurnal Antropologi: Isu-Isu Sosial Budaya 21, no. 01 (2019): 1-9.

${ }^{14}$ Elia Nurindah Sari and Samsuri, "Etnosentrisme Dan Sikap Intoleran Pendatang Terhadap Orang Papua," Jurnal Antropologi: Isu-Isu Sosial Budaya 22, no. 1 (2020): 142-50, https://doi.org/10.25077/jantro.v22.n1.p142-150.2020.

15 Ardi Priyatno Utomo, "Kronologi Kematian George Floyd Setelah Ditindih Derek Chauvin," Kompas.com, 2020.
} 
A Part of History That Has Never Been Lost | Farras Kartika Kusumadewi, Moses Glorino Rumambo Pandin

the city of Minneapolis needs to struggle to overcome racial segregation and inequality, especially in education and health, which is still happening. ${ }^{16}$

\section{Impact and Solutions to Racism Cases}

Conflicts that occur in multicultural societies are inseparable from the limitations of the term "conflict," which etymologically comes from the Latin "con" which means together and "fligere" which means collision or collision. In another sense, conflict is a social process that takes place by involving people or groups who oppose each other with threats of violence. Conflict can also be interpreted as a conflict of power and interest between one group and another in the process of competing for relatively limited social resources (economic, political, social and cultural). Conflicts like this can also be referred to as racial conflicts, namely conflicts between different racial groups because of conflicting interests and cultures, which generally occur because one race feels like the most superior and most perfect group. The racial conflicts that occur will of course, hurt the life of a multicultural society. Below are some of the negative impacts, namely:

1. If the conflict is not successfully resolved, causing violence or war, the group unity will be destroyed.

2. There is a change in individual personality such as being violent, aggressive and irritable, especially if the conflict leads to violence.

3. The destruction of existing social values and norms

4. Generate discriminatory attitudes towards certain races or groups

5. Causing anarchic actions against other groups

6. Resulting in false religious fanaticism

7. Resulting in mutual hostility between races and religions.

8. Legalize the slave trade. One example of justification for racism is that sub-Saharan Africans are claimed to have been born slaves because of the (biblical) curse of the sin that Ham had committed.

9. They are degrading the dignity of human position. An example is an assertion that Native Americans are not rational beings as different from the Spaniards as apes are from humans.

\footnotetext{
${ }^{16}$ Oktoviana Banda, "Diskriminasi Ras Dan Hak Asasi Manusia Di Amerika Serikat: Studi Kasus Pembunuhan George Floyd," Jurnal Sosiologi Pendidikan Humanis 5, no. 2 (2020): $120-33$.
} 
A Part of History That Has Never Been Lost | Farras Kartika Kusumadewi, Moses Glorino Rumambo Pandin

10. Resulting in the massacre of a group of people, segregation and racial violence and even genocide. ${ }^{17}$

In Indonesia, it has various ethnic groups, religions, and races, but sometimes these differences can cause someone to be racist. In today's era, technology is developing very rapidly, with the development of this technology, it can affect changes in various fields, such as economic, social, political, and cultural. This also affects lifestyle changes, including consumption patterns to the way people sell and shop. ${ }^{18}$ In Indonesia, social media users reach $56 \%$ of the total population. With social media, access to information can be easily obtained, starting from Facebook, YouTube, Instagram and others. Social media can be used as a forum for solutions to racism cases by, for example, sharing about the dangers of racism, making posters or articles not to be racist and so on. This might be easy to accept, considering that the people who are mostly active on social media are millennials. ${ }^{19}$

The high possibility of racism and discrimination among Indonesian people will continue to occur because of the perspective of the Indonesian people themselves who prefer the similarity of ethnicity, religion and race in their respective spheres of life. They find it challenging to accept diversity or differences in ethnicity, religion and race to incorporate into the scope of their life. From several cases of racism that occurred in Papuans, there were incidents of clashes carried out by Papuans against the local government as an act of protest. ${ }^{20}$ The possibility of the high number of racism and discrimination in the community has a relationship with the low understanding of 'Bhinneka Tunggal Ika' in the motto of the Indonesian state as outlined in the education curriculum based on citizenship education to be applied in everyday life in society. The need for addition and affirmation of the civics education curriculum to be presented is not only mostly theoretical but accompanied by real practice to make it more understandable and easy to apply in everyday life so that it is easy to accept various ethnic groups,

\footnotetext{
${ }^{17}$ N, Hannase, and Satiri, "Solusi Konflik Rasial Pada Masyarakat Multikultural Dalam Perspektif Al-Qur' an."

18 "Statistik E-Commerce 2019," Badan Pusat Statistik, 2019.

${ }^{19}$ Nur Hidayati et al., "Menangkal Rasisme Di Era Digital," Prosiding National Conference for Community Service Project (NaCosPro), vol. 2, 2020.

20 Sari and Samsuri, "Etnosentrisme Dan Sikap Intoleran Pendatang Terhadap Orang Papua."
} 
A Part of History That Has Never Been Lost | Farras Kartika Kusumadewi, Moses Glorino Rumambo Pandin

religions and races to blend in with all ethnic differences as Indonesian citizens who good to obey the motto of his country. ${ }^{21}$

Many foreign films usually tell about elements of racism, whether based on original stories or not, one example is the Green Book film. Several scenes in the film reflect a fight against racism experienced by a character of color named Don Shirley who works as a pianist, with his white co-worker named Tony Vallelonga. In the Green Book film, a fight is also depicted through actions that are will not be disclosed to others, as is communication. In communication in the scope of psychology, there is a communication process that is only done to oneself, namely personal communication (Intrapersonal Communication). In this communication concept, it is stated that a person has a self-concept that affects human beings, how an individual views himself, and other people view the individual's self which influences the patterns of self-interaction. In this film, it also concludes that an anarchic mass act or action does not always represent resistance through physical contact. A relationship that exists within a certain period of time can open a person's eyes and heart so as to create a sense of mutual understanding. From that feeling produces an acceptance and tolerance. This act of acceptance and tolerance is often obtained from exposure to social life around us. With a sense of patience, it can be a way out for a problem that shackles, such as the case of racism. ${ }^{22}$

\section{Conclusion}

The diversity of races and ethnicities in the world can be an advantage and can also be a trigger for conflict. The conflict that occurred was racial conflict. This problem has occurred since ancient times and today it still happens a lot even though today's society is a modern society that sometimes emphasizes human values. Even in this modern era, there are still many cases of racism from various parts of the world. For example, in America, in 2020, the death of George Floyd occurred which eventually led to massive demonstrations in America demanding equality and justice for African-Americans. In Indonesia alone in 2019, an incident occurred when

21 Avuan Muhammad Rizki and Rona Apriandini Djufri, "Pengaruh Efektivitas Pembelajaran Bhineka Tunggal Ika Terhadap Angka Rasisme Dan Diskriminasi Di Indonesia 2019," Jurnal Penelitian Agama, vol. 6, 2020.

${ }^{22}$ Miranda Mariani Wijaya and Mutiah, "Perlawanan Rasisme Di Amerika Dalam Film Green Book," Commercium, vol. 02, 2019. 
A Part of History That Has Never Been Lost | Farras Kartika Kusumadewi, Moses Glorino Rumambo Pandin

the police arrested 43 Papuan students at their dormitory in Surabaya, East Java, to tarnish the Indonesian Red and White flag during the Independence Day Award. This incident resulted in a wave of people in Papua shedding their disappointment in Jayapura, the capital of Papua, and in Manokwari, the capital of West Papua, and the City of Sorong who demanded racism against Papua be eliminated.

Many factors cause racial conflicts, and the triggers are different in each country that experiences them. Factors that often trigger these actions, among others, are due to injustice, oppression, and racial discrimination by certain groups against other groups. Racism arises among high-ranking societies forming a global hierarchy of superiority. Through the cases of intolerance acts above, one thing that the researcher thinks can be concluded is how before disputes between groups occurred, actually it started from problems that occurred between individuals. An attitude of tolerance is the main thing to stem this.

\section{Reference}

\section{Books}

Djaelani, Mustofa. Metode Penelitian bagi Pendidik. Diedit oleh Mei Aulia. Jakarta: Pt. Multi Kreasi Satudelapan, 2010.

Wahono, Asri Oktavianty, Asia Foundation, dan Solidaritas Nusa Bangsa. Reformasi Hukum Terhadap Kebijakan Diskriminasi Ras dan Etnis di Indonesia. Jakarta: Solidaritas Nusa Bangsa (Organization); Asia Foundation, 2003.

\section{Journals}

Adrian, Defira Martina, Fence M Wantu, dan Abdul Hamid Tome. "Diskriminasi Rasial Dan Etnis Dalam Perspektif Hukum Internasional.” Jurnal Legalitas 14, no. 6 (2021).

Anand, Divya, dan Laura M. Hsu. "COVID-19 and Black Lives Matter: Examining Anti-Asian Racism and Anti-Blackness in US Education." Open Journals in Education (OJED) 5, no. 1 (2020).

Banda, Oktoviana. "Diskriminasi Ras dan Hak Asasi Manusia di Amerika Serikat: Studi Kasus Pembunuhan George Floyd." Jurnal Sosiologi 
A Part of History That Has Never Been Lost | Farras Kartika Kusumadewi, Moses Glorino Rumambo Pandin

Pendidikan Humanis 5, no. 2 (2020).

Hidayati, Nur, Renny Christiarini, Amanda Rosetia, Violina Anastasya,

Tiara Sonita, Evita Kordinata, Habeebanisya, et al. "Menangkal Rasisme Di Era Digital." Prosiding National Conference for Community Service Project (NaCosPro). Vol. 2, 2020.

Irab, Yenita. “Rasisme.” Jurnal Jaffray 5, no. 1 (2007).

Lane, Max. "The Papuan Question in Indonesia: Recent Developments." ISEAS - Yusof Ishak Institute 9, no. 74 (2019).

N, Abd Muid, Mulawarman Hannase, dan Iwan Satiri. "Solusi Konflik Rasial pada Masyarakat Multikultural dalam Perspektif Al-Qur' an." Mumtäz 2, no. 2 (2018).

Purbasari, Verbena Ayuningsih, dan Suharno. "Interaksi Sosial Etnis CinaJawa Kota Surakarta.” Jurnal Antropologi: Isu-Isu Sosial Budaya 21, no. 01 (2019).

Rizki, Avuan Muhammad, dan Rona Apriandini Djufri. "Pengaruh Efektivitas Pembelajaran Bhineka Tunggal Ika Terhadap Angka Rasisme dan Diskriminasi di Indonesia 2019." Jurnal Penelitian Agama. Vol. 6, 2020.

Sari, Elia Nurindah, dan Samsuri. "Etnosentrisme dan Sikap Intoleran Pendatang Terhadap Orang Papua." Jurnal Antropologi: Isu-Isu Sosial Budaya 22, no. 1 (2020): $142-50$. https://doi.org/10.25077/jantro.v22.n1.p142-150.2020.

Tirahmawan, Jaza, Bryan Atfis Luthfi Melody, dan Muhammad Naufal Nur Ahly. "Rasisme Terhadap Kulit Hitam dalam Iklan H\&M." Jurnal Audiens 2, no. 1 (2021).

Umarela, Farid Hamid, Nindyta Aisyah Dwityas, dan Devi Rosfina Zahra. "Representasi ideologi supremasi kulit putih dalam iklan televisi." ProTVF 4, no. 1 (2020).

Wijaya, Miranda Mariani, dan Mutiah. "Perlawanan Rasisme Di Amerika Dalam Film Green Book.” Commercium. Vol. 02, 2019. 
A Part of History That Has Never Been Lost | Farras Kartika Kusumadewi, Moses Glorino Rumambo Pandin

\section{Thesis}

Kimberly, Andrea. "Media Sosial dalam Pergerakan: Twitter dan Facebook sebagai Kampanye Gerakan Black Lives Matter di Amerika Serikat." Universitas Katolik Parahyangan, 2018.

S., Crusita Maharani. "Konstruksi Pemberitaan Stigma Anti-China Pada Kasus Covid-19 Di Kompas.Com.” Universitas Islam Negeri Syarif Hidayatullah, 2020.

\section{Website}

Warta Ekonomi.co.id. "Beijing Murka, Media Jerman Tulis 'Coronavirus Made in China,", 2020. https://www.wartaekonomi.co.id/read270642/beijing-murka-mediajerman-tulis-coronavirus-made-in-china.

Utomo, Ardi Priyatno. "Kronologi Kematian George Floyd Setelah Ditindih Derek Chauvin." Kompas.com, 2020. https://www.kompas.com/global/read/2020/06/04/214401970/kronologi -kematian-george-floyd-setelah-ditindih-derek-chauvin?page=all.

Badan Pusat Statistik. "Statistik E-Commerce 2019," 2019. https://www.bps.go.id/publication/2019/12/18/fd1e96b05342e479a8391 7c6/statistik-e-commerce-2019.html. 